\title{
The City in Late Imperial China
}

Edited by G. William Skinner. Sixteen papers by social scientists and institutional historians examine various aspects of the traditional Chinese city. The editor has contributed two long papers and introductions to the book's three parts: "The City in History," "The City in Space," and "The City as a Social System." Illustrated with 58 maps and plates, the work also includes special endpaper maps showing the cities of China in I 894 classified according to size, administrative level, and economic importance. $\$ 35.00$

\section{The Confessions of Lady Nijo}

Translated from the Japanese by Karen Brazell. Reissue of a 1973 paperback; first U.S. cloth edition. "Surely there can be few comparable books in the world, and Karen Brazell's fine translation makes it a joy to read."-Donald Keene. "An extraordinary memoir composed in I 307 but undiscovered until I940. . . Provides source material on the life of the imperial court during a time which has been poorly documented and insufficiently studied."--Choice. Cloth, \$I2.50; paper, \$3.95

\section{The Kamakura Bakufu}

A Study in Documents. Jeffrey P. Mass. Foreword by Takeuchi Rizo. This pioneering guide to the content and use of documents in the study of medieval Japan consists of annotated translations of I 77 warrior-related records from Japan's Kamakura age, together with an annotated and geographically classified Bibliography of nearly 600 published works presenting pre-r 600 official documents. Includes explanatory notes, an extensive glossary, alphabetical and chronological indexes, and a photograph section containing representative original documents and commentary. \$I 7.50

\section{Stanford University Press}




\section{TWO GREAT WORKS}

\section{易經集成}

\section{I ching chi ch'eng}

A Collection of Books on The Book of Changes

compiled by

Prof. Yen Lin-feng

US $\$ 1,974.00$

plus postage

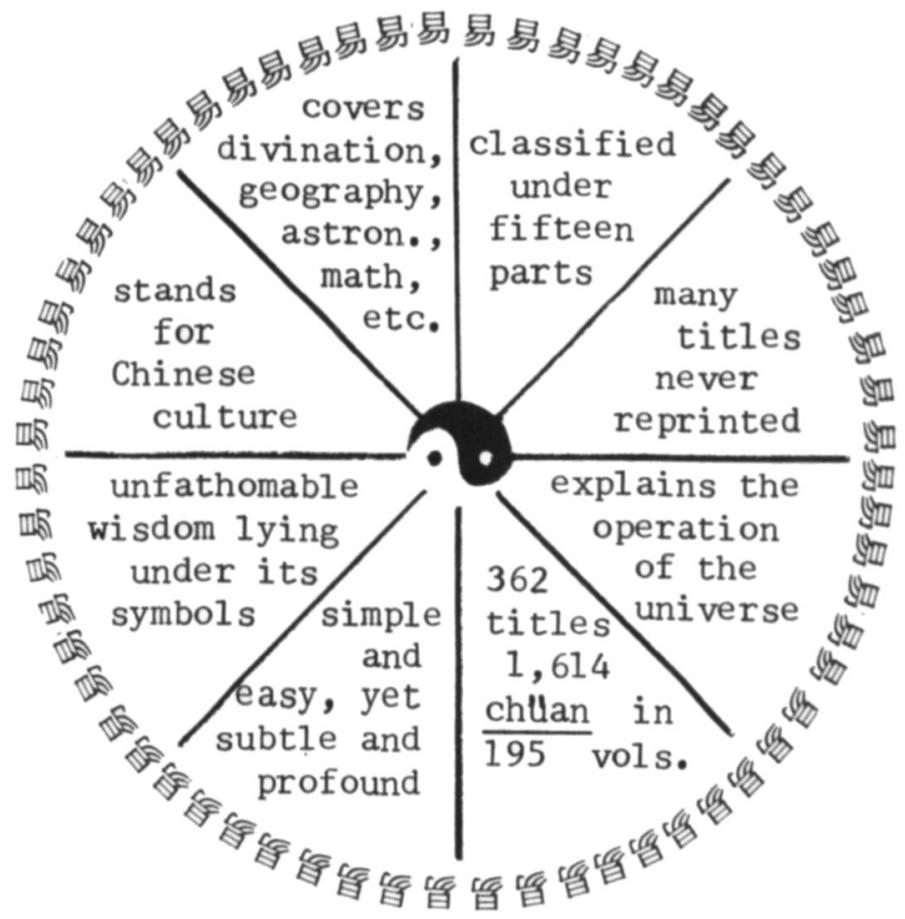

\section{墨子集成}

\section{Mo tzu chi ch'eng}

A Collection of Books on the Mo-tzu compiled by

Prof. Yen Lin-feng

US $\$ 480.00$

plus postage

Mo-tzu, a philosopher of the Warring States period (480-221BC), spent most of his life working for the welfare of others. His doctrines of charity (love without distinction), anti-warism, equality, and thrift are reflected in the fifteen-section book Motzu and for a time kept pace with those of the Confucianists.

This collection brings together the results of much hard work by both ancient and modern scholars. It also contains various editions of Motzu from the early Ming to the present. A total of 371 chüan are bound in 46 volumes. A detailed index to authors is included.

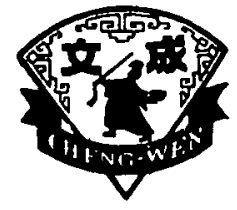

Please forward orders and inquiries to:

成文出版社有限公司

CH'ENG WEN PUBLISHING CO., LTD. (Asia \& other areas)

P.O. Box 22605, Taipei, Taiwan, Republic of China

CHINESE MATERIALS CENTER, INC. (USA \& Europe)

809 Taraval St., San Francisco, CA 94116, U.S.A. 
Communist states have never practiced free flow of information. Popular knowledge of mainland China, therefore, is restricted to reports issued by official sources in Peking, which seldom tell more than one side of the story. Do you wish to enlarge your knowledge of the real situation on the Chinese mainland? Please subscribe to
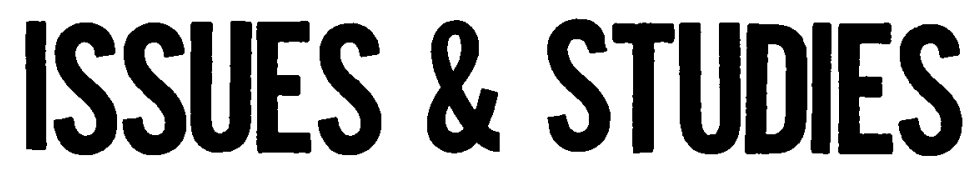

an objective academic journal published monthly in Taipei. Each issue is devoted to discussion and analysis of problems relating to Chinese Communism and other Communist systems in general. Key features in recent issues are shown below.

\section{January 1977 issue}

The October Coup in Peiping and Its Aftermath Ch'iu K'ung-yuan How Much Must One Know to Think Straight? Stefan T. Possony The Development of the Leftist Literary Consciousness

in Modern China

Constantine Tung

PERSONALITY: Huang Hua-Newly Appointed Foreign Minister DOCUMENTS: Chou En-lai's Reports on the International Situation; Keng P'iao's Talks on "A Turning Point in the ChinaU.S. Diplomatic Relations" (Excerpts)

\section{February 1977 issue}

Upheaval on the Chinese Mainland: Possible Outcome

Tsai Wei-ping

Hua Kuo-feng's Initial Alteration of Mao's Economic Line Lin Ch'en

CCP Power Shift and the Chiang Ch'ing Incident Yao Meng-hsiian PERSONALITY: Nieh Jung-chen-Vice-Chairman of the CCP Military Affairs Commission

DOGUMENT: Radio Moscow's Criticism of Mao Tse-tung

US $\$ 10$ per year by sea mail US\$20 per year by air mail

Subscriptions should be addressed to

\section{INSTITUTE OF INTERNATIONAL RELATIONS}

64 Wan Shou Road, Mucha, Taipei, Taiwan

Republic of China 


\section{"Certain to be \\ the standard guide to the literature \\ of Tokagowa Japan."}

-The Kirkus Reviews

From Donald Keene, the Western world's most eminent authority on Japanese literature, comes "an encyclopedic history . . . written with masterly erudition and discernment."*

In the first of three volumes, Keene's unparalleled study brings to life the people, the culture, and the literary traditions of Japan's middle period-with penetrating analyses of major authors.

"The erudition and scholarship are impressive indeed. If there is anyone else on the scene who has been through such a body of difficult material and is prepared to organize it with such care and intelligence, one is hard put to think who it might be.

-EDWARD G. SEIDENSTICKER,

The Chronicle of Higher Education

".. . definitive as it surely must be, it is rich with other pleasures, both of history and art."

- HORTENSE CALISHER

“... provides the crucial information we need for a more intelligent grasp of a magnificent body of literature ... and the people who created it."

-SANTHA RAMA RAU

". . . not only exhaustive, but always readable and often amusing."

-ANTHONY THWAITE

The New York Times Book Review'

\section{Donald Keene's WORLD WITHIN WALLS}

\section{Japanese Literature of the Pre-Modern Era 1600-1867 \\ $\$ 22.95$}

383 Madison Avenue, New York, NY 10022

*The Kirkus Reviews

Holt, Rinehart \& Winston 


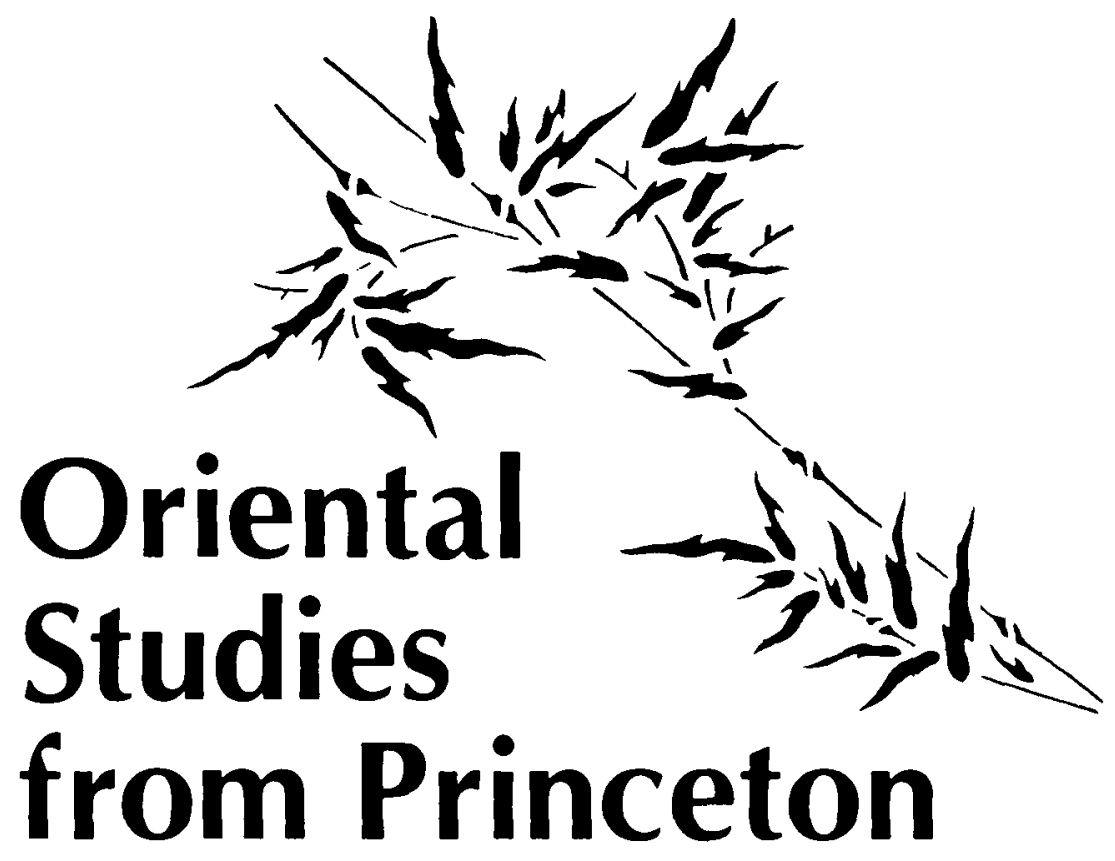

The Chinese Communist Treatment of Counterrevolutionaries, 1924-1949

Patricia Griffin

Griffin contends that an understanding of how the Chinese Communists created a legal system at a time of rapid shifts in the political culture is essential to a grasp of more recent events. Focusing on the Communists' definition and treatment of counterrevolutionaries, she describes and assesses the contribution of environment, ideology, and leadership in the development of legal techniques used by the Communists in their rise to power. Studies in East Asian Law, Harvard University $\$ 15.00$

\section{Legal Reform in Occupied Japan}

A Participant Looks Back

Alfred C. Oppler

After a distinguished career as a jurist in Germany, Alfred Oppler came to the U.S. in 1939, and in 1946 he was invited to Tokyo, where he was SCAP's authority on reform of the Japanese legal order to implement the principles of the new Constitution. "A major contribution to the study of the postwar legal reform in Japan. It is much more valuable because of the author who played a major part in the reform work." - Shigemitsu Dando $\$ 20.00$

\section{Parties Out of Power in Japan, 1931-1941}

\section{Gordon Mark Berger}

"Gordon Berger's fine study provides the fullest account of Japanese politics in the 1930s and helps explain the decline of political parties as well as the failure to replace them completely. Its richness of documentation and careful analysis guarantee it an important place in the literature for many years to come."-Marius B. Jansen, Princeton University $\$ 20.00$ 


\section{Modernization and the Japanese Factory}

Robert M. Marsh and Hiroshi Mannari

"No other study to my knowledge penetrates the work attitudes and performance of industrial employees in present-day Japan as exhaustively as this book does. The materials are original and quite comprehensive. The analysis is painstakingly careful. The findings should be of great interest and value to scholars in several fields." - Solomon B. Levine, University of Wisconsin Cloth, $\$ 27.50 \bullet$ Limited Paperback Edition, $\$ 11.50$

\section{Archetype and Allegory in the Dream of the Red Chamber}

\section{Andrew H. Plaks}

Surprisingly little has been written in Western languages about the 18thcentury Chinese novel Dream of the Red Chamber, perhaps the supreme masterpiece of its entire tradition. In this study, Plaks has used the conceptual tools of comparative literature to focus on the novel's allegorical elements and narrative structure. He also provides a significant demonstration that critical concepts derived from Western literary models may be fruitfully applied to Chinese narrative works. Illus. $\$ \$ 15.50$

\section{Artists and Traditions}

\section{Uses of the Past in Chinese Culture}

\section{Edited by Christian F. Murck}

The essays in this book are concerned with a central problem in Chinese cultural history-its relation to its own past. Originally presented at a colloquium held in conjunction with the exhibition of Chinese paintings "In Pursuit of Antiquity" at The Art Museum, Princeton University, the papers represent the thought of specialists in intellectual history, literature, social history, and art history, on the subject of creativity within a continuing tradition in China. A Publication of The Art Museum, Princeton University. Illus. - $81 / 2 \times 10^{\prime \prime}$ • $\$ 35.00$

\section{Japanese Ink Paintings from}

\section{American Collections: The Muromachi Period}

An Exhibition in Honor of Shuiiro Shimada

Edited by Yoshiaki Shimizu and Carolyn Wheelwright

The art of ink painting, with its enormous expressive possibilities, came to Japan from China, becoming a fully lapanese tradition during what is known as the Muromachi period, from the 14 th to the 16 th centuries. Thirty-seven works in American collections have been chosen from the period for reproduction and detailed discussion in this catalogue, which records an exhibition mounted in 1976 by The Art Museum, Princeton University. A Publication of The Art Museum, Princeton University 120 illus. • 11 × 11\%" • Cloth, $\$ 40.00$ - Paperback, $\$ 18.00$

Now in Paperback

Tradition and Modernization in

Japanese Culture

Edited by Donald $\boldsymbol{H}$. Shively

"A large and important book."-Journal of the American Oriental Society Studies in the Modernization of Japan

$\$ 5.95 \bullet$ (Cloth, \$14.50)

PRINCETON UNIVERSITY PRESS Princeton, New Jersey 08540 


\section{New from Princeton ...}

\section{The Vietnam War and International Law \\ Volume 4: The Concluding Phase \\ Edited by RICHARD A. FALK}

This concluding volume of The Vietnam War and International Law focuses on the last stages of America's combat role in Indochina. Contributors to this volume-lawyers, scholars, and government officials-include Dean Rusk, Eugene V. Rostow, Richard A. Falk, John Norton Moore, and Richard Wasserstrom. Sponsored by the American Society of International Law Cloth, \$35.00 • Limited Paperback Edition, \$13.50

\section{The Politics of Cultural Nationalism in South India MARGUERITE ROSS BARNETT}

Barnett analyzes a successful political movement in South India that used cultural nationalism as a positive force for change. By exploring the history of Dravida Munnetra Kazhagam party, the author provides a new perspective on political identity and challenges the interpretation of cultural nationalism as an inherent threat to the integrity of territorially defined nation-states and to the progress of modernization.

\section{PRINCETON UNIVERSITY PRESS}

Princeton, New Jersey 08540

THE PERFORMING ARTS PROGRAM OF THE ASIA SOCIETY is pleased to announce the following programs available in 1977-1978.

PENCA (The Art of Self-Defense) and TOPENg BABAKAN (Masked Dance) from Sunda, West Java Twelve Persons

Penca is unique in that the movements of self-defense so popular throughout Asia have been set to a distinctive type of music provided by drums, a reed instrument, and a small gong.

In Topeng Babakan, a single dancer, accompanted by gamelan music, portrays five different types of characters, using beautifullywrought masks - the dancer losing his identity and becoming the character represented by the mask.

Availability: East-October 5-31, 1977; Midwest-November 1-14, 1977; West-November 15-22, 1977.

THOVIL (The Ritual Chanting, Dance, and Drumming of Exorcism) from Sri Lanka Six Persons

From the south of Sri Lanka (Ceylon) comes this exciting ceremonial: witch doctors wearing demon masks dance, eat fire, twirl torches to the accompaniment of the yak-bere (devil drum) and chant in invocation of the spirits. The colorfu! costumes, exotic masks, and acrobatic dances have remained unchanged for centuries, and will give a glimpse of shamanism as it is still practiced in Sri Lanka today.

Availability: East-February 1-25, 1978; Midwest-February 26-March 8, 1978; West-March 9-22, 1978.

\section{QAWWALI MUSIC FROM PAKISTAN Ten Persons}

This inspiring devotional music, which is the musical expression of the Sufis, is vocal music pertormed by soloists and ensemble singers accompanied by drum, harmonium, and handelapping. The repetition of certain phrases of qawwali poetry (which emphasizes mystical love or praise of God, the Prophet, and saints) builds towards a state of ecstasy.

Availability: East-March 7-24, 1978; Midwest-March 25-April 2, 1978; West-April 3-13, 1978.

All three groups will be avallable for concerts, master-classes, lecture-demonstrations and in-residencies. For further information please write to Mrs. Beate Gordon, Director. The Performing Arts Program of The Asia Society, 133 East 58 th Street. 15th floor, New York, N.Y. 10022. Telephone: 212-371-4758 or 212-751-3280. 


\section{The Vedic Experience Mantramañjari}

An Anthology of the Vedas

for Modern Man and

Contemporary Celebration

Raimundo Panikkar

The most crucial texts of the Indian Sacred Scriptures-in all, more than 500, newly translated in to contemporary English-are collected in this anthology. The commentaries and translations do not give a specifically western, Christian, or Hindu interpretation, but try to make the texts intelligible to the modern reader by presenting ancient wisdom in its own clearest light. This is a book for meditation, for reading, public and private, as well as for thorough study at the wellspring of human wisdom.

800 pages, Illustrated, $\$ 25.00$

\section{China after the Cultural Revolution}

\section{Jürgen Domes}

Translated from the German by David Goodman

Domes draws on an astonishing amount of information-found in radio dispatches from outlying provinces, confidential official reports, and the likegenerally overlooked by foreign analysts. Emphasizing political rather than social or economic aspects of developments between 1969 and 1973, his acute insights help to make the tortured course of the Cultural Revolution more readily understandable.

350 pages, $\$ 15.00$

\section{Regional Government and Political Integration}

Southwest China, 1949-1954

\section{Dorothy J. Solinger}

In considering regionalism and political integration in Southwest China during the years in which the country was divided into six Great Administrative Regions, Solinger reviews the political, cultural, and economic separatism that was endemic in the Southwest and the administrative process by which the area was integrated into the Chinese nation.

300 pages, 5 charts, 6 maps, $\$ 17.50$

Now in Paperback-

Japanese Industrialization and its Social Consequences Edited by Hugh Patrick

This book examines aspects of Japanese industrialization and its effect on social change from the mid-nineteenth century to the present.

At bookstores 515 pages, $\$ 6.95$

\section{ses}

UnIUERSTY OP CALIPORAL PRESS BERHELEY 9\$7R० 


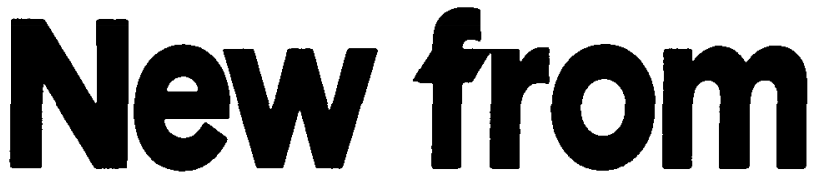

LOVE SONG OF THE DARK LORD

Jayadeva's Gitagovinda

BARBARA STOLER MILLER, Editor and Translator

This translation of Jayadeva's Gitagovinda, which has been called the most beautiful lyric poem of classical Sanskrit literature, comes in both a cloth edition for scholars containing complete critical apparatus and a paperback edition for students and general readers.

Translations from the Oriental Classics

cloth, $\$ 17.50$; paper, $\$ 3.95$

CHINESE LITERATURE

Volume II: Nature Poetry

H. C. CHANG

This collection of Chinese nature poetry, including the works of T'ao Yüan-ming, Hsieh Ling-yün, Wang Wei, Meng Hao-jan, and Liu Tsung-yüan, is the second in a projected six-volume series. Also available is Volume 1 , Popular Fiction and Drama.

$\$ 8.00$

Published by Universitetsforlaget and distributed in the U.S. and Canada by Columbia University Press:

\section{INVITATION TO CHINESE PHILOSOPHY \\ Eight Studies \\ ARNE NAESS and ALASTAIR HANNAY, Editors}

An introduction to Chinese philosophy, suitable for the general reader as well as students of philosophy, this treatise focuses on the main ideas of Chinese philosophers in the different, though related, traditions of Taoism, Confucianism, Neo-Confucianism, and Buddhism.

Universitetsforlaget

$\$ 13.00$, paper

\section{AN ANTHOLOGY OF BUDDHIST TANTRIC SONGS PER KVARNE}

This is the first complete translation and comprehensive study of some fifty Buddhist tantric songs, composed some time from the ninth to the twelfth century A.D., to appear outside India. Written primarily for the Buddhist specialist, but of interest to Indologists and the general reader as well, the book analyzes the imagery and profound doctrine revealed in the songs.

Universitetsforlaget

$\$ 16.00$, paper 


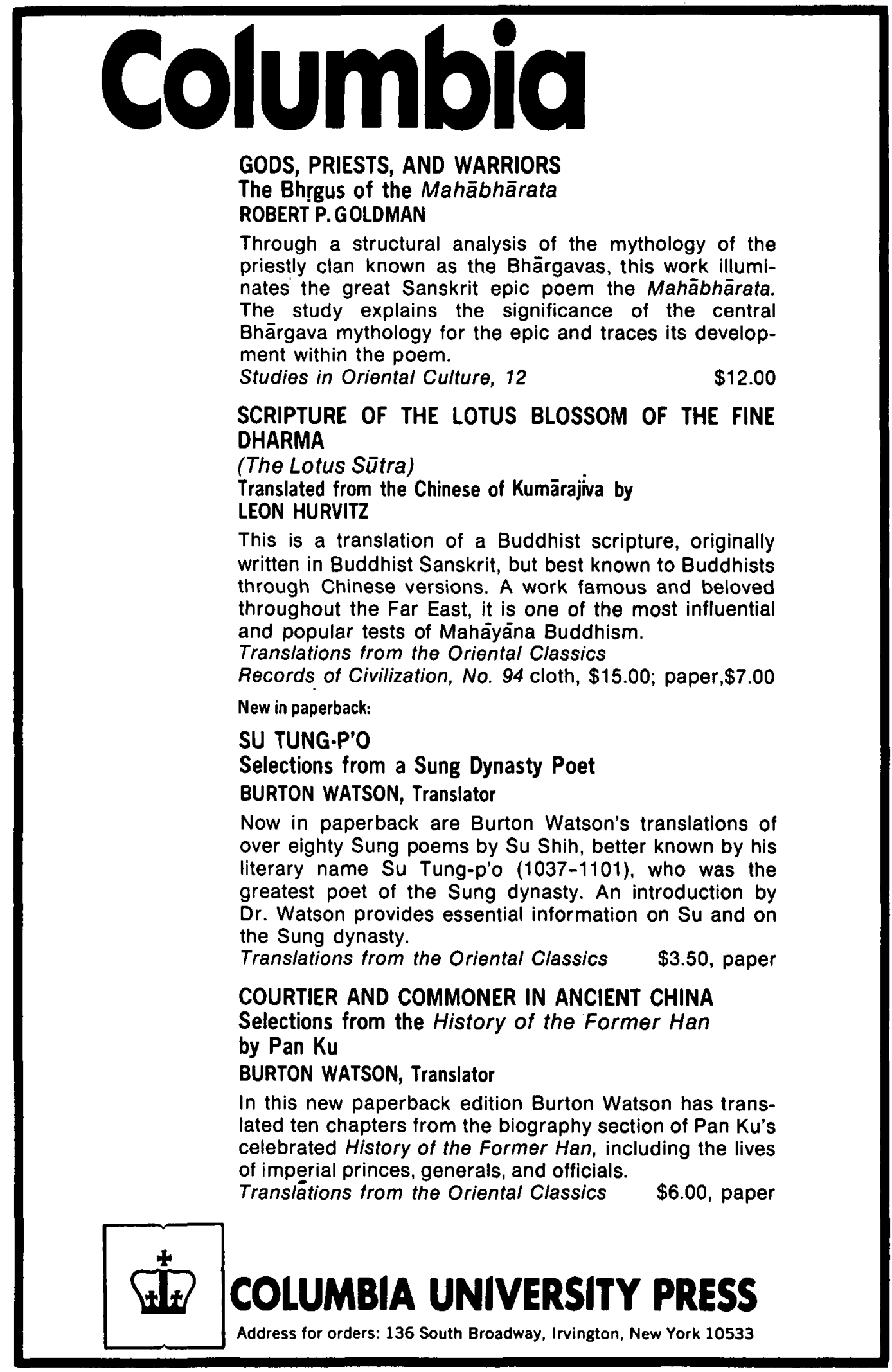




\section{Sir Aurel Stein}

Archaeological Explorer

JEANNETTE MIRSKY

Among his many accomplishments, Sir Aurel Stein rediscovered the ancient Silk Route between China and the West and unearthed dozens of cities long buried in Central Asia. Jeannette Mirsky's fascinating biography includes sixteen pages of photographs.

580 pages Illus. Cloth $\$ 17.50$

\section{The Journey to the West}

\section{Volume 1}

TRANSLATED AND EDITED BY ANTHONY C. YU

This first complete English translation since its publication in the late sixteenth century recounts the sixteen-year pilgrimage of the monk Hsüan-tsang (596-664) to India. Volume 1 includes an introduction to the work as a whole and an annotated translation of the first twenty-five chapters. 544 pages Cloth $\$ 25.00$

\section{From Mandeville to Marx}

The Genesis and Triumph of Economic Ideology LOUIS DUMONT

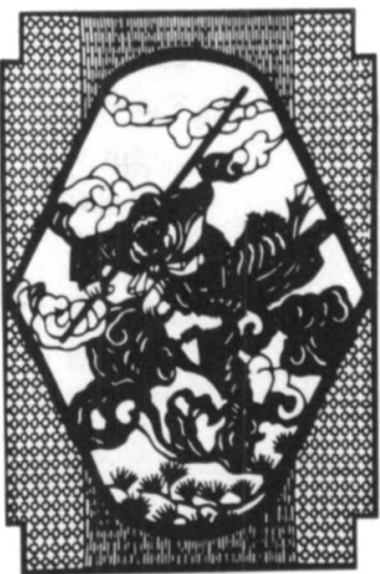

Tracing the writings of Locke, Mandeville, Adam Smith, and especially Marx, Dumont analyzes the progressive ideological disengagement of the economic dimension from religion, politics, and morality in the West. 240 pages Cloth $\$ 16.50$

\section{What is Taoism?}

And Other Studies in Chinese Cultural History HERRLEE G. CREEL

"This volume . . . affords one of the first detailed views of Taoism's relationship to governmental patterns as then developed in the late Chou, Ch'in and Han dynasties."-Choice vii, 192 pages Paper $\$ 3.95$

\section{UNIVERSITY OF CHICAGO PRESS}

\section{Chicago 60637}




\section{A NEW HISTORY OF INDIA}

STANLEY WOLPERT, University of California, Los Angeles. This survey analysis portrays the transformation of South Asian Civilization from its Indus Valley culture over 4,000 years ago to the subcontinental Nation States of India, Pakistan, and Bangladesh. The complex nature of Hinduism, the institutional characteristics of ancient India's great Imperial unifications and early urbanization, the impact of Islam and of Muslim conquests on the culture and society of North India, and the process of Western commercial penetration are reviewed and analyzed. India's subsequent modernization, National Liberation struggle and separatist Muslim Independence movement that led to the birth of Pakistan, as well as the era of Independent India's Raj and the emergence of Bangladesh, are reconstructed in a humanistic synthesis of cultural, political, and socio-economic history. 1977

$$
448 \text { pp.; } 10 \text { maps }
$$

\section{THE RISE OF MODERN CHINA}

Second Edition

IMMANUEL C.Y. HSÜ, University of California, Santa Barbara. "It is by far the best general history of modern China that exists."-Perspective. "The best textbook to date on modern China. Comprehensive, thorough, scholarly, yet eminently readable. Hsü's mastery of the subject matter is evident throughout." -Dilip Basu, University of California, Santa Cruz. "Remains an excellent one-volume presentation of the major historical trends...."-E-tu Zen Sun, Pennsylvania State University 1975

$$
1,024 \text { pp.; } 88 \text { illus. }
$$

\section{SOUTHEAST ASIA}

\section{A History}

LEA E. WILLIAMS, Brown University. After briefly surveying the early history of Southeast Asia, Professor Williams focuses on the modern period in a narrative centered on historical themes rather than on individuals and events. He illustrates how the peoples of tropical East Asia have been caught up in the same broad historical currents, and depicts the region as an arena of struggle from the time of prehistoric folk migrations. 1976

$$
320 \text { pp.; } 15 \text { illus.; } 8 \text { maps }
$$

Prices are subject to change.

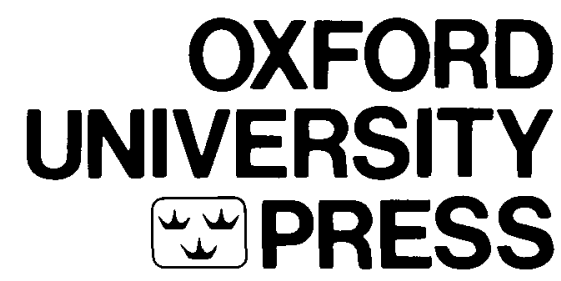




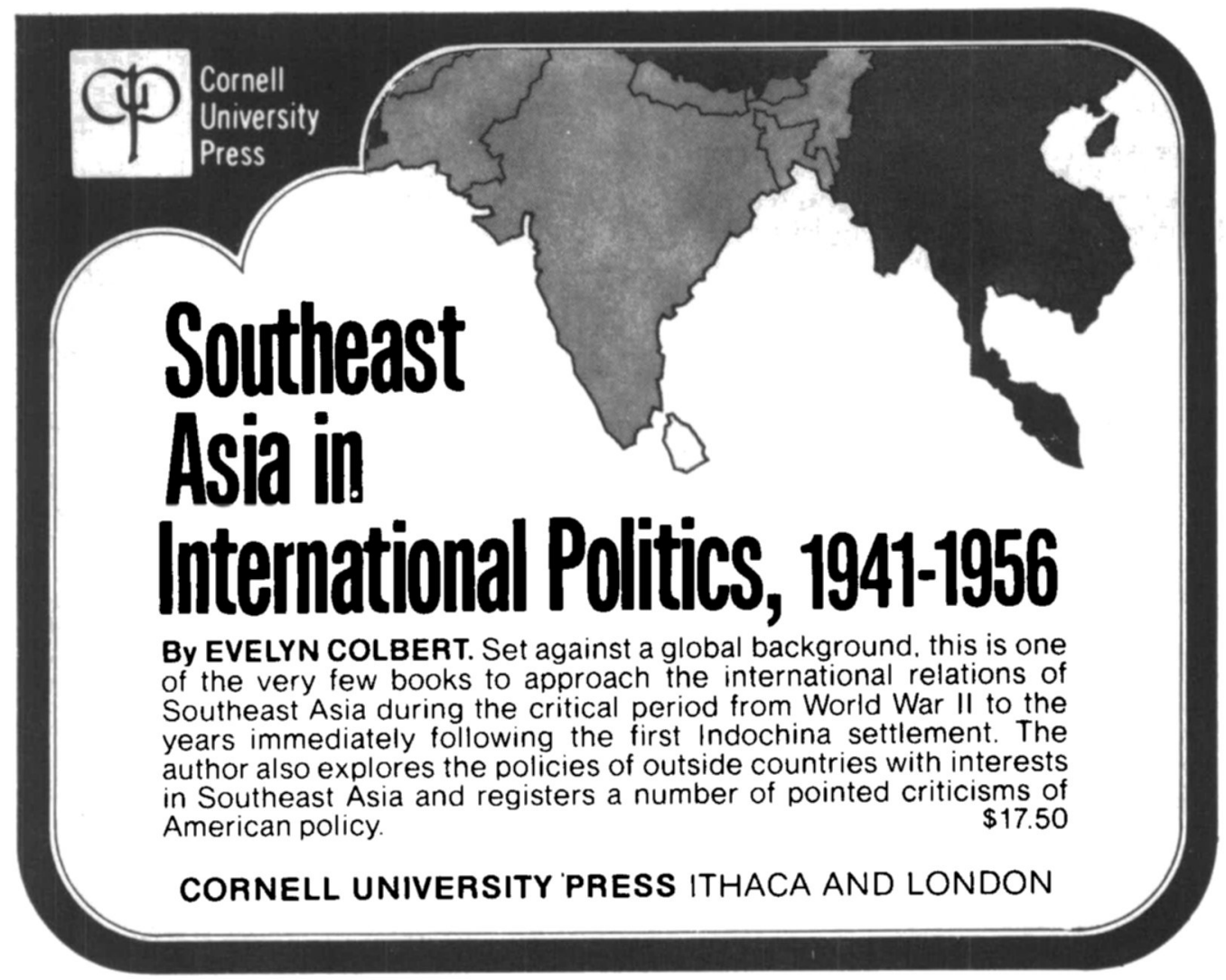

\section{New ORBIS Title}

\section{LOVE AND STRUGGLE IN MAO'S THOUGHT}

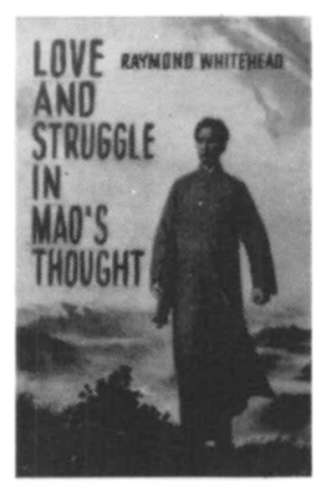

by Raymond Whitehead

This study of Mao's ethic faces head-on the features of Mao's thought that are so difficult for us in the West to accept: class struggle, "brain-" washing," revolutionary violence, hatred of the class enemy, worldwide spread of revolution, anti-individualism. This is a sympathetic yet critical appreciation of the ethical teaching of the man who has done so much to shape the twentieth century. "I am convinced," writes Whitehead, "that we are dealing not simply with ideas, but with the great realities of our era. I hope this book helps readers to come to a new awareness of the ethical choices they face in a world of oppression and struggle."

Raymond L. Whitehead has been Asia Research Consultant for the National Council of Churches and a faculty member of the Chinese University of Hong Kong. Co-author of China! Inside the People's Republic (Bantam), his articles have been published in Christian Century. Christian Science Monitor, Christianity and Crisis and the International Review of Mission.

ISBN 0-88344-2892 CIP

Cloth $\$ 8.95$

ISBN $0.88344-2906$

Paper $\$ 3.95$

Write for free ORBIS catalog 


\section{INDIA}

INDIAN FOREIGN POLICY

\section{The Nehru Years}

edited by B. R. Nanda

Based on a series of lectures delivered in the Nehru Memorial Museum and Library in 1973-1974, the essays in this volume are by scholars specializing in international relations and by diplomats who have witnessed Indian foreign poli$c y$ in the making. More than a decade after Nehru's death, it is possible to see the framework of his policies in clearer perspective.

ANEAST.WEST CENTER BOOK 王 $\$ 9.95$

\section{THE AGE}

DISTRIBUTION OF THE INDIAN POPULATION

\section{A Reconstruction}

\section{for the States and}

\section{Territories, 1881 -1961}

by Sudhansu Bhusan Mukherjee

India is unique among developing countries in having an unbroken series of decennial population censuses covering more than a century. Professor Mukherjee has constructed a consistent series of age and sex distributions for an eighty-year period for twenty-nine uniformly defined states and territories of contemporary India and has presented this data in convenient, usable form.

Distributed for the Population Institute. East-West Cenier

paper, $\$ 5.00$
IMPERIAL CRIME AND PUNISHMENT The Massacre at Jallianwala Bagh and British Judgment, 1919-1920

\section{by Helen Fein}

Why do people authorize and condone violence against those of different ethnic and racial groups-violence that would be punishable if committed against their own group? This study of the massacre that killed more than 500 unarmed Indians in the Punjab and caused educated Indians to lose faith in British justice shows how a social order based on membership in racial, ethnic, religious, or national groups tends to produce class crimes and class solidarity. The author's conclusions have implications not only for the study of colonial situations, but also for an understanding of present-day race relations, criminal justice in multi-ethnic societies, and genocide.

$\$ 12.00$

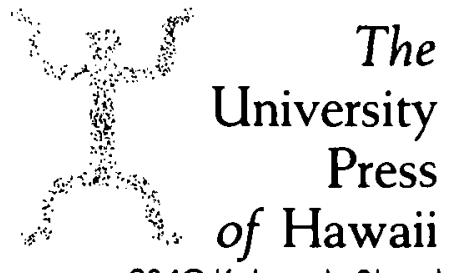

2840 Kolowalu Street Honolulu, Hawaii 96822 


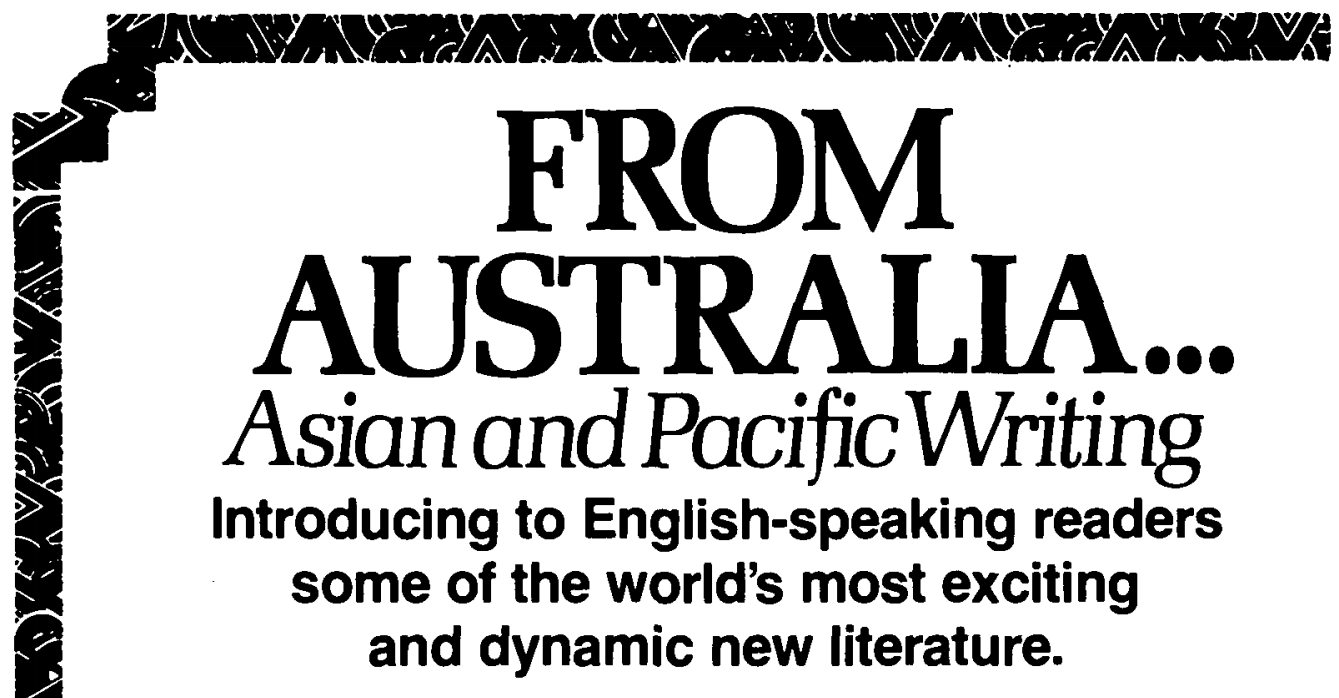

\section{Atheis}

Achdiat K. Mihardja - Translated by R.J. Maguire

A novel of emergent Indonesia set in Java during World War II. Presents with passion and power two facets of Indonesian life, the conventional docility of villagers and the revolutionary intensity of communists. "An abstract yet very accomplished and intense study."-Bulletin P.E.N. International. 180 pages, $\$ 9.30$ hardcover (ISBN 0-7022-0766-7);

$\$ 4.25$ paperback (ISBN 0-7022-0765-9)

\section{Padma River Boatman}

Manik Bandopadhyaya

- Translated by Barbara Pointer \& Yann Lovelock

Bandopadhyaya's greatest novel portrays with unique understanding and sympathy the boatmen, fishermen, palm-trappers, weavers and peasants of Bangladesh. A "classic of Indonesian 'social realism'..."

- Asian Studies Assn. of Australia Newsletter. 142 pages, $\$ 9.30$ hardcover (ISBN 0-7022-0833-7);

$\$ 4.25$ paperback (ISBN 0-7022-0834-5)

\section{Tropical Gothic}

Nick Joaquin

A brilliant collection of short stories. "Nick Joaquin is the Filipino writer whose works English-speaking foreigners must read if they want to know what shifting gears from a Spanish past to an American-influenced present has done to Filipinos." - M.S.T. English Quarterly. 271 pages, \$10.00 hardcover (ISBN 0-7022-0775-6); $\$ 4.25$ paperback (ISBN 0-7022-0776-4) 


\section{A Heap of Ashes}

Pramoedya Ananta Toer - Translated and Edited by Harry Aveling Five stories by one of Indonesia's leading writers, a brilliant story-teller with a superb sense of place and emotional atmosphere. "The three central ones should be required reading for anyone hoping to understand the Indonesia of the 1930s and 1940s."

-Asian Studies Assn. of Australia New/sletter. 193 pages, $\$ 9.30$ hardcover (ISBN 0-7022-1060-9);

$\$ 4.25$ paperback (ISBN 0-7022-1071-4)

\section{Contemporary Indonesian Poetry Translated and Edited by Harry Aveling}

"The emergence of Bahasa Indonesia... has been accompanied by a ferment of creative writing, much of which has been unavailable to Western readers. This volume presents a selection of seven Indonesian poets published in the post-Sukarno 'guided democracy' period.... The translations are generally excellent."-Choice.

261 pages, \$9.30 hardcover (ISBN 0-7022-0931-7);

$\$ 4.25$ paperback (ISBN 0-7022-0932-5)

\section{Black Writing From New Guinea Edited by Ulil Beier}

Reminiscences, stories, poems and plays by 18 contemporary writers representing a multitude of cultural traditions-capture a world in transition as Papua New Guinea achieves independence, and present it for the first time directly, not through the eyes of the traveller.

152 pages, $\$ 9.30$ hardcover (ISBN 0-7022-0835-3);

$\$ 4.25$ paperback (ISBN 0-7022-0846-9)

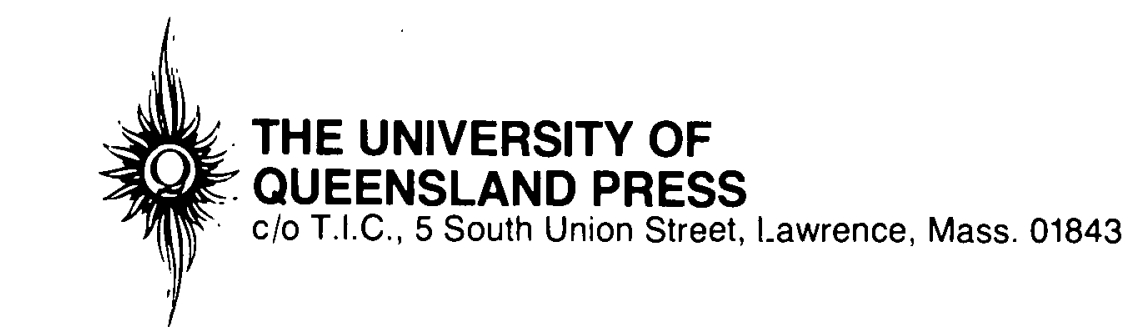




\section{Food in Chinese Culture}

Anthropological and Historical Perspectives

edited by K. C. Chang

This wide-ranging study of the Chinese food tradition presents a unique analysis of a culture through its eating habits.

"Opens a new direction of research, analysis, and interpretation in both sinological studies and comparative studies on various cultures."-Cho-yun Hsu Illus. \$20.00

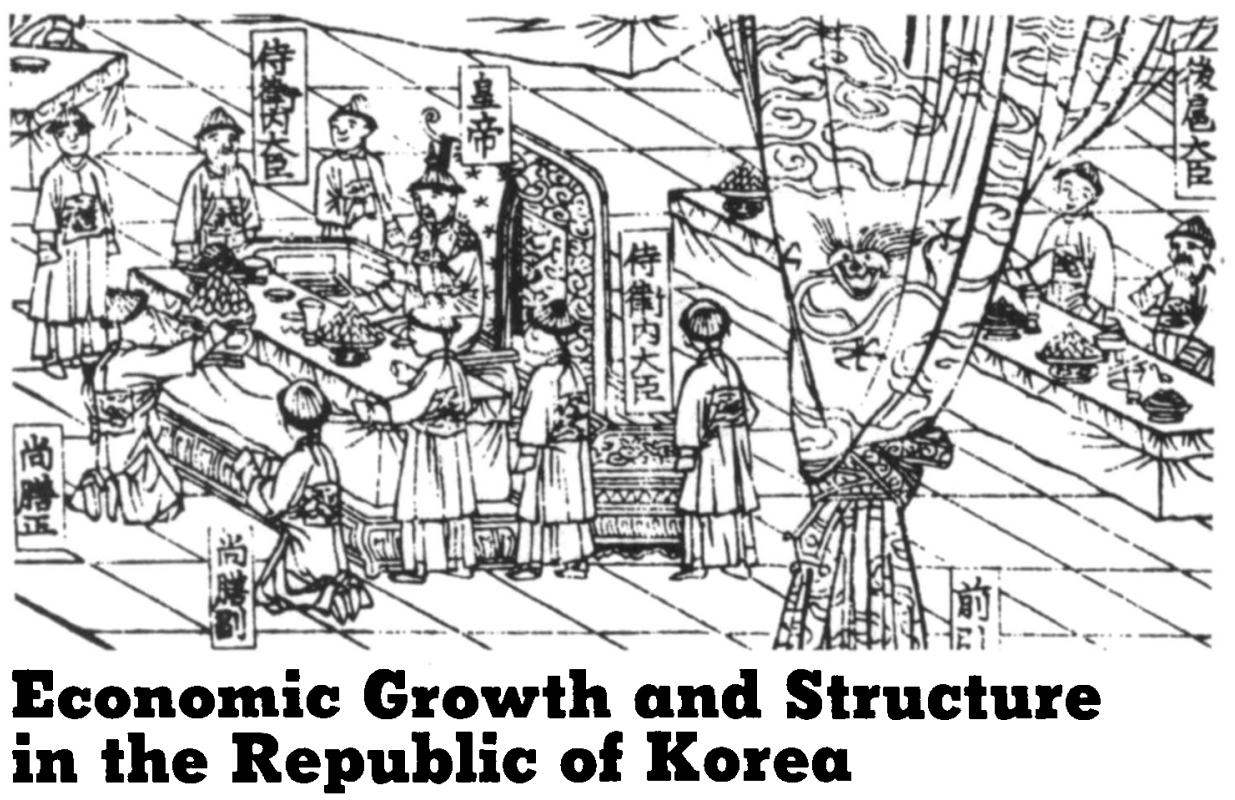

Paul W. Kuznets

A study of the history, causes, and consequences of the accelerated growth of the South Korean economy since the end of the Korean War. Kuznets compares his findings for Korea with data on Taiwan, Japan, and the United States, as he examines whether the Korean experience has differed from that of other countries and, if so, for what reasons. \$I 6.50

\section{Cambodian Literary Reader and Glossary Cambodian-English Glossary}

Franklin E. Huffman and Im Proum

The reader contains thirty-two selections from some of the most important and best-known works of Cambodian literature in a variety of genres.

The glossary contains more than I 0,000 items, making it the largest Cambodian-English glossary compiled to date. The definitions are more general and complete than one usually finds in a simple reader glossary, in which definitions are normally context-specific.

Because the glossary is so useful in itself, it is being made available separately as well as bound with the reader.

Reader and Glossary Paper \$20.00 Glossary Paper \$10.00

\section{Yale University Press New Haven and London LE}




\section{WAR CRIMINAL \\ The Life and Death of Hirota Koki by Saburo Shiroyama translated by John Bester}

War criminal? Here is an inside view of the dramatic events surrounding the former Foreign and Prime Minister of Japan sentenced to death by the Far East Tribunal after World War II. In the thirties, Hirota tried in vain to suppress the rising tide of jingoistic militarism. Yet, during the trials in which he was designated as one of the principal men responsible for the war, Hirota said nothing in his own defense.

Beneath the narrative, author Saburo Shiroyama poses the larger question of the validity of war crimes tribunals and explores the complexities of the confrontation between government and military. Fascinating reading.

Awarded the Mainichi publishing prize and the Yoshikawa Eiji literary prize. 310 pages, plus 8 pages of photographs. $\quad \$ 10.00$ available June

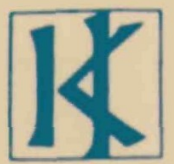

KODANSHA INTERNATIONAL 10 East 53rd Street

New York, N.Y. 10022

Write for catalog. 


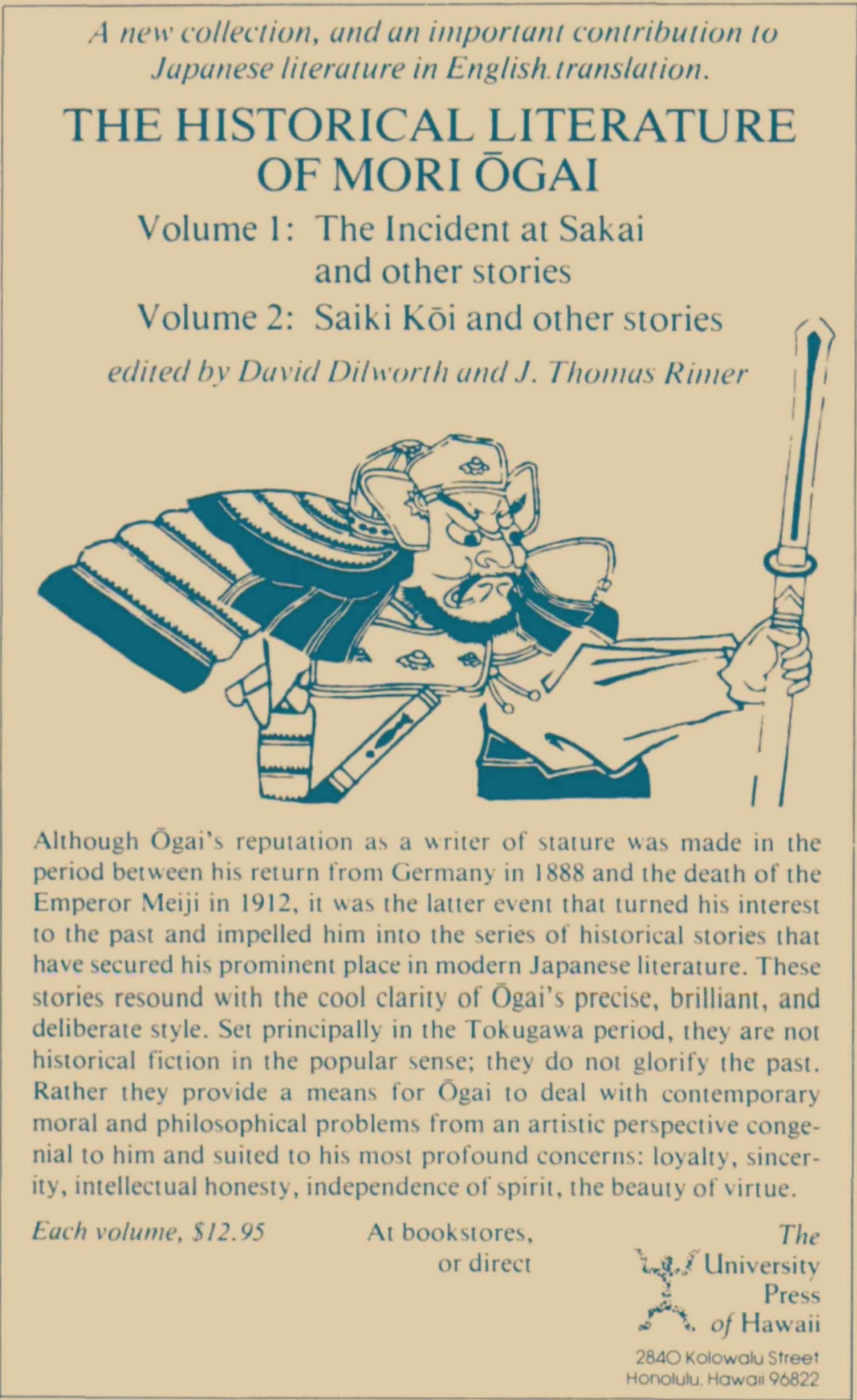

